\title{
1 Transmission dynamics and epidemiological characteristics of Delta variant infections \\ 2 in China
}

4 Min Kang $^{1^{*}}$, Hualei Xin ${ }^{2 *}$, Jun Yuan ${ }^{3}$, Sheikh Taslim Ali ${ }^{2,4}$, Zimian Liang ${ }^{5}$, Jiayi Zhang ${ }^{1}$,

5 Ting $\mathrm{Hu}^{1}$, Eric H. Y. Lau ${ }^{2,4}$, Yingtao Zhang ${ }^{1}$, Meng Zhang ${ }^{1}$, Benjamin J. Cowling ${ }^{2,4}$, Yan $\mathrm{Li}^{1+}$,

6 Peng $\mathrm{Wu}^{2,4}$

7

$8 *$ These authors contributed equally (joint first authors).

$9 \ddagger$ These authors contributed equally (joint senior authors).

\section{Affiliations:}

12 1. Guangdong Provincial Center for Disease Control and Prevention, Guangdong province,

13 China

14 2. WHO Collaborating Centre for Infectious Disease Epidemiology and Control, School of

15 Public Health, Li Ka Shing Faculty of Medicine, The University of Hong Kong, Hong Kong

16 Special Administrative Region, China.

17 3. Guangzhou Center for Disease Control and Prevention, Guangdong province, China

18 4. Laboratory of Data Discovery for Health Limited, Hong Kong Science Park, New

19 Territories, Hong Kong.

20 5. Foshan Center for Disease Control and Prevention, Guangdong province, China

\section{Corresponding authors:}

23 Benjamin J. Cowling, School of Public Health, Li Ka Shing Faculty of Medicine, The

24 University of Hong Kong, 7 Sassoon Road, Pokfulam, Hong Kong

25 Tel: +852 3917 6711; Email: bcowling@hku.hk 
medRxiv preprint doi: https://doi.org/10.1101/2021.08.12.21261991; this version posted August 13, 2021. The copyright holder for this preprint (which was not certified by peer review) is the author/funder, who has granted medRxiv a license to display the preprint in perpetuity.

It is made available under a CC-BY-NC-ND 4.0 International license .

26 and

27 Yan Li, Guangdong Provincial Center for Disease Control and Prevention, Guangdong

28 province, China;

29 Tel: +86 2031051493; Email: sjkzx_liyan@gd.gov.cn

30

31 Running head: Epidemiology of Delta variant in China

32

33 Word count (abstract): 248

34 Word count (main text): 3,338

35

36 
medRxiv preprint doi: https://doi.org/10.1101/2021.08.12.21261991; this version posted August 13, 2021. The copyright holder for this preprint (which was not certified by peer review) is the author/funder, who has granted medRxiv a license to display the preprint in perpetuity.

It is made available under a CC-BY-NC-ND 4.0 International license .

\section{ABSTRACT}

38 Background: The Delta variant of SARS-CoV-2 has become predominant globally. We

39 evaluated the transmission dynamics and epidemiological characteristics of the Delta variant

40 in an outbreak in southern China.

41 Methods: Data on confirmed cases and their close contacts were retrospectively collected

42 from the outbreak that occurred in Guangdong, China in May-June 2021. Key

43 epidemiological parameters, temporal trend of viral loads and secondary attack rates were

44 estimated and compared between the Delta variant and the wild-type SARS-CoV-2 virus. We

45 also evaluated the association of vaccination with viral load and transmission.

46 Results: We identified 167 patients infected with the Delta variant in the Guangdong

47 outbreak. The mean estimates of the latent period and the incubation period were 4.0 days

48 and 5.8 days, respectively. A relatively higher viral load was observed in Delta cases than in

49 wild-type infections. The secondary attack rate among close contacts of Delta cases was 1.4\%,

50 and $73.9 \%$ (95\% confidence interval: $67.2 \%, 81.3 \%$ ) of the transmissions occurred before

51 onset. Index cases without vaccination (OR: $2.84,95 \%$ confidence interval: $1.19,8.45)$ or

52 with one dose of vaccination (OR: 6.02, 95\% confidence interval: $2.45,18.16)$ were more

53 likely to transmit infection to their contacts than those who had received 2 doses of

54 vaccination.

55 Discussion: Patients infected with the Delta variant had more rapid symptom onset. The

56 shorter and time-varying serial interval should be accounted in estimation of reproductive

57 numbers. The higher viral load and higher risk of pre-symptomatic transmission indicated the

58 challenges in control of infections with the Delta variant. 
medRxiv preprint doi: https://doi.org/10.1101/2021.08.12.21261991; this version posted August 13, 2021. The copyright holder for this preprint (which was not certified by peer review) is the author/funder, who has granted medRxiv a license to display the preprint in perpetuity.

It is made available under a CC-BY-NC-ND 4.0 International license .

\section{INTRODUCTION}

61 The SARS-CoV-2 Pango lineage B.1.617.2, also known as the Delta variant, is a variant of

62 SARS-CoV-2 first detected in India on 7 September 2020 (1). It was classified by the World

63 Health Organization as a "Variant of Concern" on 11 May 2021, and has been rapidly

64 outcompeting other variants of SARS-CoV-2 and becoming predominant in many locations

65 around the world. As of 3 August 2021, a total of 135 countries have reported cases of the

66 Delta variant, and over $80 \%$ of new infections globally were expected to be due to Delta

67 since mid-June $(1,2)$.

68

69 Compared to the wild-type virus, the Delta variant has 9-10 characteristic mutations

70 including T19R, G142D, 156del, 157del, R158G, L452R, T478K, D614G, P681R, and

71 D950N which could be responsible for competitive advantages against other variants (3).

72 Residue 452 spike mutation located at the receptor binding domain may increase capability of

73 immune evasion and resistance to antibody neutralization, and P681R in the S1/S2 regions of

74 S gene could influence proteolytic processing (4). All these mutations could result in

75 increased affinity of ACE2 and resistance to antibody neutralization therefore leading to

76 increases in transmissibility (4). The basic reproduction number $\left(\mathrm{R}_{0}\right)$ of Delta variant was

77 suggested to be $55 \%-97 \%$ higher than other variants (2).

On 21 May 2021 the first local Delta case in mainland China was identified in Guangdong province. A local outbreak occurred in the following days and weeks, and the gene sequence analysis showed that all cases identified in this outbreak were infected with the Delta variant

82 and could be traced back to the index case (5). Aggressive case finding strategy including

83 multiple comprehensive large-scale nucleic acid tests in high-risk communities, routine PCR

84 testing for close contacts quarantined in designated places and nucleic acid screening among 
inpatients and outpatients in clinical institutions, had been strictly implemented aiming to identify all infected persons and rapidly control this outbreak. This provides uniquely rich epidemiological data on infections with the Delta variant. In this study, we aimed to explore the transmission dynamics and epidemiological characteristics of the Delta variant outbreak in China. As the coverage of COVID-19 vaccination has increased substantially in China since March 2021, we were able to examine the associations between vaccination and virus shedding and transmission.

\section{METHODS}

\section{Data collection}

We retrospectively collected information on all laboratory-confirmed symptomatic and asymptomatic cases with Delta (B.1.617.2) variant infection from the outbreak in Guangdong province in May and June 2021. To estimate the latent period distribution, we collected individual information on the first and last dates of exposure (exposure window), and the repeated laboratory testing dates of last negative PCR test (lower bound of viral shedding) and first positive PCR test (upper bound of viral shedding) which provide a window during which detectable virus shedding began. We also obtained illness onset dates for incubation period estimation. We reconstructed the transmission pairs from available illness onset dates for both infectors and infectees to estimate the serial interval distribution, the infectiousness profile, and the proportion of transmission occurring prior to symptom onset. Severity status including asymptomatic, mild, moderate, severe and critical were collected for each case, along with other information such as sex, age, pre-existing underlying conditions, vaccination status, and exposure duration. We also collected information on close contacts of the confirmed Delta cases to estimate secondary attack rates and identify predictors of infection. 
medRxiv preprint doi: https://doi.org/10.1101/2021.08.12.21261991; this version posted August 13, 2021. The copyright holder for this preprint

110 Comprehensive large-scale nucleic acid-testing strategies, including community-wide PCR

111 testing, routine test among concentrated quarantine close contacts and daily test for inpatients,

112 were implemented in every local COVID-19 outbreak in China since April 2020 (6). For each

113 case, serial samples were collected and tested for both $\mathrm{N}$-gene and OR-gene from the date of

114 first positive PCR test until discharge from hospital. To understand the temporal dynamics of

115 viral RNA shedding for the Delta variant, we obtained serial cycle threshold $(C t)$ values for

116 each case for $\mathrm{N}$-gene with throat swabs from the first time of positive test $(C t$ value $<40)$. To

117 make a comparison of viral loads between the Delta variant and the wild-type variant, we

118 used data of wild-type SARS-CoV-2 infections that were identified in Guangzhou, China in

119 early 2020 from a published paper on individual cases with daily test results (7).

\section{Case definitions}

122 A patient is confirmed as a COVID-19 case based on a positive result of PCR for SARS-

123 CoV-2 with respiratory specimens. Virus strains in this study were determined by the

124 sequenced genome and were classified based on the "Pango lineages" rule (8). The time

125 interval between infection and becoming infectious is defined as the latent period, that could

126 be compared with the incubation period which describes the time duration between infection

127 and symptom onset. The latent period is typically proxied by the time from infection until an

128 infected person has virus shedding that is detectable by PCR, and can be shorter than the

129 incubation period for some COVID-19 cases when virus shedding becomes detectable prior

130 to symptom onset. The serial interval, defined as the time interval between successive

131 symptom onsets in a transmission chain, is an important parameter for estimating many other

132 key epidemiological parameters, such as $\mathbf{R}_{0}$, the expected number of secondary cases

133 generated from one primary case in a completely susceptible population, and the

134 instantaneous reproduction number $\left(\mathrm{R}_{\mathrm{t}}\right)$ which describes the expected number of secondary 
medRxiv preprint doi: https://doi.org/10.1101/2021.08.12.21261991; this version posted August 13, 2021. The copyright holder for this preprint (which was not certified by peer review) is the author/funder, who has granted medRxiv a license to display the preprint in perpetuity.

It is made available under a CC-BY-NC-ND 4.0 International license .

135 cases caused by one typical primary case at time $t$. The infectiousness profile of COVID-19

136 describes the duration and intensity of infectiousness of infected cases which imply the

137 probability of transmission during the infectious period.

139 We assessed the clinical severity of COVID-19 cases via clinical classification into

140 asymptomatic, mild, moderate, severe and critical following the Guidelines in Diagnosis and

141 Treatment of COVID-19 ( $8^{\text {th }}$ version) published by National Health Commission since 15

142 April $2021(9)$.

144 Close contacts were defined as individuals who were exposed to symptomatic COVID-19

145 cases within two days before their illness onset, or exposed to asymptomatic cases at close

146 proximity $(<1$ meter) without wearing proper personal protection equipment within two days

147 before their sampling dates of the first positive samples for SARS-CoV-2. Close contacts

148 were classified as household and extended family, social, community and healthcare contacts

149 based on the definitions previous published by Sun et al (10). Cases were considered having

150 effective 1-dose vaccination if the start date of exposure was 10 days after the first dose of

151 vaccination or later, or having effective 2-dose vaccination if the start date of exposure was

15214 days after the second dose of vaccination or later $(11,12)$.

\section{$154 \quad$ Statistical analysis}

155 We used a maximum likelihood-based inferential method to estimate the distributions of

156 latent period, incubation period and serial interval and the infectiousness profile of confirmed

157 COVID-19 cases by fitting Gamma distributions. We accounted for the interval censoring of

158 exposure and viral shedding windows when estimating the latent period and incubation

159 period distributions. To estimate the infectiousness profile for symptomatic cases, we used a 
medRxiv preprint doi: https://doi.org/10.1101/2021.08.12.21261991; this version posted August 13, 2021. The copyright holder for this preprint (which was not certified by peer review) is the author/funder, who has granted medRxiv a license to display the preprint in perpetuity.

It is made available under a CC-BY-NC-ND 4.0 International license .

160 method previously published by He et al. (7) which considered the serial interval as a

161 convolution between the infectiousness profile and the incubation period and allowed for an

162 early occurrence of infectiousness before symptom onset.

164 The time-varying forward serial intervals $(13,14)$ and daily numbers of cases were used to 165 estimate the daily $\mathrm{R}_{\mathrm{t}}$ by applying the statistical methods developed by Cori et al (15). The

166 serial interval distribution and $\mathrm{R}_{0}$ were obtained by using mean estimates of the serial interval 167 and $\mathrm{R}_{\mathrm{t}}$ during the exponential growth phase of the Delta outbreak (14).

169 The overall temporal trend of $C t$ values for $\mathrm{N}$-gene for Delta cases was analyzed by day of

170 illness onset. To aid visualization, smoothing splines using generalized additive models

171 (GAMs) (including days of illness onset as the only predictor) were fitted to the $C t$ values to

172 characterize the overall trend for the Delta variant. To make a comparison between Delta and

173 wild-type, we also fitted the temporal trend of $C t$ values for the Delta variant and wild-type

174 separately by excluding severe and critical and vaccinated Delta cases, because no severe or

175 critical or vaccinated cases were identified in wild-type cases. To evaluate the impact of

176 vaccination on viral loads among Delta cases, we fitted a multivariate GAMs by including

177 variables of vaccination (1: without vaccination, 2: with one or two dose of vaccine), days of

178 illness onset, age and disease severity. Temporal trend of predicted $C t$ values from the GAMs

179 model was presented and compared using box plots for vaccinated and unvaccinated cases

180 separately.

182 Close contacts of confirmed COVID-19 cases infected with Delta variant with a solely

183 possible source of infection for each close contact were included for analyzing. The overall

184 secondary attack rate was calculated by dividing the number of infections by the total number 
medRxiv preprint doi: https://doi.org/10.1101/2021.08.12.21261991; this version posted August 13, 2021. The copyright holder for this preprint (which was not certified by peer review) is the author/funder, who has granted medRxiv a license to display the preprint in perpetuity.

It is made available under a CC-BY-NC-ND 4.0 International license .

185 of close contacts. To assess the effectiveness of vaccination against transmission, a stepwise

186 logistic regression model was fitted by including age, sex, disease severity of the index,

187 COVID-19 vaccination for index cases, COVID-19 vaccination for close contacts, type of

188 contact, presence of exposure on the symptom onsets of index cases and duration of exposure.

189 Non-parametric and parametric bootstrap approach with 1000 resamples was used to assess

190 the uncertainty of each estimated parameter. Analyses were carried out using R version 4.0.3

191 (R Foundation for Statistical Computing, Vienna, Austria).

\section{RESULTS}

194 As of 18 June 2021, 167 Delta cases were identified in the outbreak in Guangdong. Sixty-

195 nine (41.3\%) were male. The median age was 47.0 years (interquartile range [IQR]: 31.0,

196 66.5) with $22(13.2 \%)$ cases aged under 15 years and 44 (26.3\%) over 65 years. The number

197 of asymptomatic, mild, normal and severe or critical was 8 (4.8\%), 29 (17.4\%), $111(66.5 \%)$

198 and 19 (11.4\%), respectively, with no reported deaths. Sixteen (9.6\%) cases received 2 doses

199 of the inactivated COVID-19 vaccine and 30 cases (18.0\%) received one vaccine dose.

201 We examined data from 101 confirmed Delta cases with sufficient information to estimate

202 the time window for infection and the time window for the start of viral shedding. The mean

203 latent period was estimated to be 4.0 days (95\% confidence interval [CI]: 3.5, 4.4). Ninety-

204 five percent of the Delta cases started shedding virus within 8.2 days (95\% CI: 7.1, 9.3) after

205 infection (Figure 1A). The mean incubation period estimated from 95 symptomatic Delta

206 cases was 5.8 days (95\% CI: 5.2, 6.4). The $95^{\text {th }}$ percentile of the incubation period for Delta

207 was 11.5 days (95\% CI: 10.1, 13.0) (Figure 1B). 
medRxiv preprint doi: https://doi.org/10.1101/2021.08.12.21261991; this version posted August 13, 2021. The copyright holder for this preprint (which was not certified by peer review) is the author/funder, who has granted medRxiv a license to display the preprint in perpetuity.

It is made available under a CC-BY-NC-ND 4.0 International license .

209 We used data from 94 transmission pairs of Delta cases with a reported onset date to estimate

210 the infectiousness profile by allowing for transmission before symptom onset. We estimated

211 that $2.7 \%$ (95\% CI: $1.0 \%, 5.0 \%$ ) of transmission occurred prior to 7 days before illness onset,

$21222.5 \%$ (95\% CI: $16.0 \%, 30.0 \%)$ started to become infectious 4 days before illness onset, and

213 the infectiousness peaked at 2.1 days (95\% CI: $1.5,2.7)$ before onset and then dropped

214 gradually, with $73.9 \%$ (95\% CI: $67.2 \%, 81.3 \%$ ) of transmission occurred before illness onset

215 and 97.1\% (95\% CI: 94.4\%, 99.0\%) of transmission occurred within 4 days after illness onset

216 (Figure 1C).

218 The estimated forward serial intervals decreased from 6.1 days (95\% CI: 5.2, 7.1) on 25 May 2021 to 4.0 days (95\% CI: 3.1, 5.0) on 18 June 2021 in the Delta outbreak (Figure 2B). By using the time varying forward serial intervals and case incidence data, we estimated that the $\mathrm{R}_{\mathrm{t}}$ dropped rapidly from 9.3 (95\% CI: $\left.7.7,11.6\right)$ on 25 May 2021 to 0.48 (95\% CI: $0.42,0.57$ ) on 18 June 2021, and had been below 1 since 9 June 2021 (Figure 2C). During the same time period, the estimated infectiousness peak shifted from 0.23 days (95\% CI: $0.20,0.26)$ after illness onset to 2.14 days (95\% CI: $1.52,2.70)$ before illness onset based on the time varying serial interval (Figure 2D). By using the daily estimates of forward serial interval and $R_{t}$ during the exponential growth phase before 27 May 2021, the initial forward serial interval was estimated to be 5.8 days (95\% CI: 5.2, 6.1) (Figure 2B), and the $\mathrm{R}_{0}$ was 6.4 (95\% CI: 3.7, 9.3) (Figure 2C).

In total, 1314 throat swabs collected between 4 days before and 34 days after illness onset were tested for 159 Delta cases. High viral loads were maintained between 4 days before onset and 7 days after onset, then decreased gradually to a low but detectable level until about 
medRxiv preprint doi: https://doi.org/10.1101/2021.08.12.21261991; this version posted August 13, 2021. The copyright holder for this preprint (which was not certified by peer review) is the author/funder, who has granted medRxiv a license to display the preprint in perpetuity.

It is made available under a CC-BY-NC-ND 4.0 International license .

234 cases with the median age of 46 years (IQR: 33,61$)$ infected with the wild-type virus in

235 Guangzhou city, Guangdong province in China between 21 January 2020 and 14 February

236 2020. Among those, 47 (50.0\%) were male, the number of asymptomatic, mild and normal

237 were $2(2.1 \%), 30(31.9 \%)$ and $61(64.9 \%)$, respectively, and no severe or critical cases were

238 identified. None of these cases received COVID-19 vaccination. In total 406 throat swab

239 samples were collected and tested on the illness onset day and 31 days after onset for the 94

240 wild-type cases. After excluding severe and critical cases and vaccinated cases, we found

241 during the period with a high viral load ( 0 to 7 days after onset), the median $C t$ values were

242 23.0 (IQR: 19.3-28.6) for N gene of the Delta variant, significantly lower than the values of

243 the wild-type N gene (median: 36.5, IQR: 33.0-40.0) (Figures 3B). Results of the GAMs

244 revealed that the $C t$ values of Delta cases who had one dose or two doses of vaccination were

245 on average 0.97 (95\% CI: $0.19,1.76)$ higher than unvaccinated cases after adjusting for days

246 of illness onset, age and disease severity (Figures 3C).

To evaluate individual infection risk and the effectiveness of vaccination on transmission for the Delta variant, we analyzed infections among 5153 individuals who were close contacts of 73 COVID-19 cases. The overall secondary attack rate was $1.4 \%$ (95\% CI: $1.1 \%, 1.8 \%$ ) in the contacts. The stepwise regression model showed that a high infection risk was among those in older age (OR: 1.02, 95\% CI: 1.01, 1.03), exposed to an index case without vaccination (OR: $2.84,95 \%$ CI: $1.19,8.45)$ or with 1 dose of vaccination (OR: $6.02,95 \%$ CI:

$2542.45,18.16$ ), and being household and extended family contacts (OR: 40, 95\% CI: 24, 66)

255 (Table 1). 
medRxiv preprint doi: https://doi.org/10.1101/2021.08.12.21261991; this version posted August 13, 2021. The copyright holder for this preprint

\section{DISCUSSION}

258 Our study provided a comprehensive assessment of the epidemiological characteristics of the

Delta variant. Higher transmissibility was demonstrated for the Delta variant, as indicated by

260 a higher reproduction number, shorter latent and incubation periods, and shorter serial

261 intervals compared to the wild-type SARS-CoV-2 $(5,13,16-18)$. We observed higher viral

262 loads in cases infected with the Delta variant which might contribute to more rapid and

263 intense transmission. In addition, we found the inactivated vaccines could effectively reduce

264 viral loads in cases infected with the Delta variant and further lead to lower transmissibility.

We estimated the time varying forward serial intervals which considered the temporal

dynamics of the disease transmission in an outbreak $(13,14)$. The $\mathrm{R}_{0}$ estimated for the Delta

variant was 6.4 which was substantially higher than the $\mathrm{R}_{0}$ of the wild-type virus at the start of the pandemic $(16,19)$. Estimation of the reproduction number could be underestimated due to unobserved infections and neglecting the changes in the forward serial interval distribution during the period of epidemic (14). In the Delta outbreak in China, active and aggressive case-finding strategies using multiple PCR tests were implemented, which was able to identify most infected persons including asymptomatic cases. With the shorter latent and incubation period, and higher secondary attack rate among household and extended family contacts, we believe multiple and more stringent interventions are needed to control epidemics of the Delta variant. During the Delta outbreak in China, the local government had implemented individual-based interventions such as case isolation, contact tracing and quarantine, as well as population-level physical distancing measures such as lockdowns and confinement $(10,13)$. More importantly, various community-wide PCR testing and routine

280 testing programmes among quarantined close contacts were aligned with the measures of contact tracing and lockdown, aiming to identify and isolate the cases as early as possible and 
medRxiv preprint doi: https://doi.org/10.1101/2021.08.12.21261991; this version posted August 13, 2021. The copyright holder for this preprint

282 interrupt transmission chains. The rapid drop in $R_{t}$ within a week (Figure $2 C$ ) indicated the 283 effectiveness of these interventions.

285 We estimated that the $73.9 \%$ of transmissions occurred pre-symptomatically for the Delta 286 variant, which was higher than other variants $(7,20,21)$, suggesting a higher transmission 287 potential of Delta cases before detection which was further supported by the high viral loads at least 4 days before illness onset shown in our study. The high risk of transmission particularly before onset indicated the need to expand contact tracing to a wider group of contacts and perhaps to a longer time scale in order to control the epidemic caused by the Delta variant $(7,22)$. However, for areas with a high prevalence of COVID-19, complete contact tracing and quarantine outside the home may be infeasible as the number of contacts is always several folds the number of infections (10). Physical distancing such as selfisolation and home quarantine is more suitable in these areas. However, society-wide physical distancing measures might increase transmission risk at household settings $(10,20)$. Our study showed that the secondary attack rate (22.0\%) among household close contacts of Delta cases was higher than the rate obtained in 2020 (12.4\%) in the same location with wild-

298 type infections (23).

We found that the viral load was higher in cases of the Delta variant than cases of the wildtype virus, indicating a potentially higher infection rate per contact for the Delta (24). In addition, patients infected with the Delta variant maintained a high viral load from 4 days before illness onset. Besides, compared to the wild type, patients infected with Delta had a slower decline in viral load towards the detection threshold of the PCR test (Figure 3B), 305 likely leading to a longer infectious period (24). Escape of the Delta variant from immunity induced by wild-type variants (25) suggests that the herd immunity threshold needed to 
medRxiv preprint doi: https://doi.org/10.1101/2021.08.12.21261991; this version posted August 13, 2021. The copyright holder for this preprint

suppress transmission of the wild-type virus may not be sufficient to control spread of the

Delta variant (24). Higher burden of SARS-CoV-2 is expected in the future given the increasing predominance of the Delta variant all over the world. Additional booster doses of vaccination might be able to increase protection against the Delta variant. appeared to diminish against infections with the Delta variant $(25,26)$. However, the efficacy of the vaccines against transmission, which is another important indicator of their impact (27), has rarely been reported. In this study, we observed that the $C t$ values among Delta cases with one or two doses of vaccination were on average 0.97 higher than the unvaccinated cases, indicating approximately 3 -fold decrease in the quantity of viral RNA copies (28). The vaccinated Delta cases in our study with a decreased viral load might have a reduced transmission potential given that viral RNA load of SAS-CoV-2 was independently associated with the shedding of transmissible viruses (29). The effectiveness of inactivated vaccines against transmission of the Delta variant demonstrated the importance of increasing vaccination coverage in mitigating COVID-19 (30).

Our study had several limitations. Self-reported symptom onset might bias estimates of the parameters, e.g., leading to an overestimation of the incubation period if patients tended to remember the later days with symptoms. Second, the $C t$ values used in our study were obtained from different diagnostic kits which shared the same detection threshold but perhaps with different sensitivity and/or specificity. Finally, in estimation of the serial interval, transmission pairs with asymptomatic cases would be excluded due to absence of symptom onset dates, which however might have biased the estimates of the reproduction number by neglecting the impact of asymptomatic transmission. 
medRxiv preprint doi: https://doi.org/10.1101/2021.08.12.21261991; this version posted August 13, 2021. The copyright holder for this preprint

(which was not certified by peer review) is the author/funder, who has granted medRxiv a license to display the preprint in perpetuity.

It is made available under a CC-BY-NC-ND 4.0 International license.

\section{2}

333 In conclusion, the Delta variant demonstrated a higher transmissibility compared to the wild

334 type of SARS-CoV-2. An extension of contact tracing period to perhaps four days prior to

335 symptom onset may be needed considering the high proportion of pre-symptomatic

336 transmission and the high viral load before onset in infections with the Delta variant.

337 Inactivated vaccines appeared to be effective in reducing transmission of Delta infections and

338 a high vaccination coverage should be pursued to reduce the burden of COVID-19 pandemic. 
medRxiv preprint doi: https://doi.org/10.1101/2021.08.12.21261991; this version posted August 13, 2021. The copyright holder for this preprint

(which was not certified by peer review) is the author/funder, who has granted medRxiv a license to display the preprint in perpetuity.

It is made available under a CC-BY-NC-ND 4.0 International license.

\section{ACKNOWLEDGMENTS}

343 The authors thank Julie Au for technical support.

\section{FUNDING}

346 This project was supported by the National Natural Science Foundation of China (No.

347 82041030); Key-Area Research and Development Program of Guangdong Province (No.

348 2019B111103001); Theme-based Research Scheme (Project No. T11-712/19-N) of the

349 Research Grants Council of the Hong Kong SAR Government; and a commissioned grant

350 from the Health and Medical Research Fund, Food and Health Bureau, Hong Kong SAR

351 Government.

352

\section{POTENTIAL CONFLICTS OF INTEREST}

354 BJC reports honoraria from AstraZeneca, GlaxoSmithKline, Moderna, Roche and Sanofi

355 Pasteur. The authors report no other potential conflicts of interest. 
medRxiv preprint doi: https://doi.org/10.1101/2021.08.12.21261991; this version posted August 13, 2021. The copyright holder for this preprint (which was not certified by peer review) is the author/funder, who has granted medRxiv a license to display the preprint in perpetuity.

It is made available under a CC-BY-NC-ND 4.0 International license .

\section{References}

358 1. B.1.617.2 Lineage Report. Alaa Abdel Latif, Julia L. Mullen, Manar Alkuzweny,

359 Ginger Tsueng, Marco Cano, Emily Haag, Jerry Zhou, Mark Zeller, Emory Hufbauer, Nate

360 Matteson, Chunlei Wu, Kristian G. Andersen, Andrew I. Su, Karthik Gangavarapu, Laura D.

361 Hughes, and the Center for Viral Systems Biology. outbreak.info, (available at

362 https://outbreak.info/situation-reports?pango=B.1.617.2). Accessed 10 July 2021.

$3632 . \quad$ World Health Organization .Weekly epidemiological update on COVID-19 - 3

364 August 2021. Coronavirus disease (COVID-19) Weekly Epidemiological Update and Weekly

365 Operational Update, (available at https://www.who.int/publications/m/item/weekly-

366 epidemiological-update-on-covid-19---3-august-2021). Accessed 5 August 2021.

367 3. Zhencui L, Kai N, Kuibiao L, Yao H, Yang S, Min K, et al. Genome Characterization

368 of the First Outbreak of COVID-19 Delta Variant B.1.617.2 - Guangzhou City, Guangdong

369 Province, China, May 2021. China CDC Weekly. 2021;3(27):587-9.

370 4. Tada T, Zhou H, Dcosta BM, Samanovic MI, Mulligan MJ, Landau NR. The Spike

371 Proteins of SARS-CoV-2 B.1.617 and B.1.618 Variants Identified in India Provide Partial

372 Resistance to Vaccine-elicited and Therapeutic Monoclonal Antibodies. bioRxiv.

$373 \quad 2021: 2021.05 .14 .444076$.

374 5. Li B, Deng A, Li K, Hu Y, Li Z, Xiong Q, et al. Viral infection and Transmission in a

375 large well-traced outbreak caused by the Delta SARS-CoV-2 variant. medRxiv.

$376 \quad 2021: 2021.07 .07 .21260122$.

377 6. Li Z, Liu F, Cui J, Peng Z, Chang Z, Lai S, et al. Comprehensive large-scale nucleic

378 acid-testing strategies support China's sustained containment of COVID-19. Nat Med.

$379 \quad 2021 ; 27(5): 740-2$.

380 7. He X, Lau EHY, Wu P, Deng X, Wang J, Hao X, et al. Temporal dynamics in viral

381 shedding and transmissibility of COVID-19. Nat Med. 2020;26(5):672-5. 
medRxiv preprint doi: https://doi.org/10.1101/2021.08.12.21261991; this version posted August 13, 2021. The copyright holder for this preprint (which was not certified by peer review) is the author/funder, who has granted medRxiv a license to display the preprint in perpetuity.

It is made available under a CC-BY-NC-ND 4.0 International license .

382 8. Rambaut A, Holmes EC, O'Toole Á, Hill V, McCrone JT, Ruis C, et al. A dynamic

383 nomenclature proposal for SARS-CoV-2 lineages to assist genomic epidemiology. Nat

384 Microbiol. 2020;5(11):1403-7.

3859 9. National Health Commission of the People's Republic of China. Guidelines in

386 Diagnosis and Treatment of COVID-19 (eighth version). (available at

387 https://www.who.int/publications/m/item/weekly-epidemiological-update-on-covid-19---6-

388 july-2021). Accessed 10 July 2021.

389 10. Sun K, Wang W, Gao L, Wang Y, Luo K, Ren L, et al. Transmission heterogeneities,

390 kinetics, and controllability of SARS-CoV-2. Science. 2021;371(6526).

391 11. World Health Organization .The Sinopharm COVID-19 vaccine: What you need to

392 know. WHO Strategic Advisory Group of Experts, (available at https://www.who.int/news-

393 room/feature-stories/detail/the-sinopharm-covid-19-vaccine-what-you-need-to-know).

394 Accessed 10 July 2021.

395 12. World Health Organization .The Sinovac COVID-19 vaccine: What you need to

396 know. WHO Strategic Advisory Group of Experts, (available at https://www.who.int/news-

397 room/feature-stories/detail/the-sinovac-covid-19-vaccine-what-you-need-to-know). Accessed

39810 July 2021.

399 13. Ali ST, Wang L, Lau EHY, Xu XK, Du Z, Wu Y, et al. Serial interval of SARS-CoV-

4002 was shortened over time by nonpharmaceutical interventions. Science.

$401 \quad 2020 ; 369(6507): 1106-9$.

402 14. Park SW, Sun K, Champredon D, Li M, Bolker BM, Earn DJD, et al. Forward-

403 looking serial intervals correctly link epidemic growth to reproduction numbers. Proc Natl

404 Acad Sci U S A. 2021;118(2). 
medRxiv preprint doi: https://doi.org/10.1101/2021.08.12.21261991; this version posted August 13, 2021. The copyright holder for this preprint (which was not certified by peer review) is the author/funder, who has granted medRxiv a license to display the preprint in perpetuity.

It is made available under a CC-BY-NC-ND 4.0 International license .

405 15. Cori A, Ferguson NM, Fraser C, Cauchemez S. A new framework and software to

406 estimate time-varying reproduction numbers during epidemics. Am J Epidemiol.

$407 \quad 2013 ; 178(9): 1505-12$.

408 16. Li Q, Guan X, Wu P, Wang X, Zhou L, Tong Y, et al. Early Transmission Dynamics

409 in Wuhan, China, of Novel Coronavirus-Infected Pneumonia. N Engl J Med.

$410 \quad 2020 ; 382(13): 1199-207$.

411 17. Xin H, Wong JY, Murphy C, Yeung A, Ali ST, Wu P, et al. The incubation period

412 distribution of coronavirus disease 2019 (COVID-19): a systematic review and meta-analysis.

413 Clin Infect Dis. 2021.

414 18. Ali ST, Yeung A, Shan S, Wang L, Gao H, Du Z, et al. Serial intervals and case

415 isolation delays for COVID-19: a systematic review and meta-analysis. Clin Infect Dis. 2021.

416 19. Du Z, Xu X, Wu Y, Wang L, Cowling BJ, Meyers LA. Serial Interval of COVID-19

417 among Publicly Reported Confirmed Cases. Emerg Infect Dis. 2020;26(6):1341-3.

418 20. Wu P, Liu F, Chang Z, Lin Y, Ren M, Zheng C, et al. Assessing asymptomatic, pre-

419 symptomatic and symptomatic transmission risk of SARS-CoV-2. Clin Infect Dis. 2021.

420 21. Ren X, Li Y, Yang X, Li Z, Cui J, Zhu A, et al. Evidence for pre-symptomatic

421 transmission of coronavirus disease 2019 (COVID-19) in China. Influenza Other Respir

422 Viruses. 2021;15(1):19-26.

423 22. Hellewell J, Abbott S, Gimma A, Bosse NI, Jarvis CI, Russell TW, et al. Feasibility

424 of controlling COVID-19 outbreaks by isolation of cases and contacts. Lancet Glob Health.

425 2020;8(4):e488-e96.

426 23. Jing QL, Liu MJ, Zhang ZB, Fang LQ, Yuan J, Zhang AR, et al. Household

427 secondary attack rate of COVID-19 and associated determinants in Guangzhou, China: a

428 retrospective cohort study. Lancet Infect Dis. 2020;20(10):1141-50. 
medRxiv preprint doi: https://doi.org/10.1101/2021.08.12.21261991; this version posted August 13, 2021. The copyright holder for this preprint (which was not certified by peer review) is the author/funder, who has granted medRxiv a license to display the preprint in perpetuity.

It is made available under a CC-BY-NC-ND 4.0 International license .

429 24. Davies NG, Abbott S, Barnard RC, Jarvis CI, Kucharski AJ, Munday JD, et al.

430 Estimated transmissibility and impact of SARS-CoV-2 lineage B.1.1.7 in England. Science.

$431 \quad 2021 ; 372(6538)$.

432 25. Liu C, Ginn HM, Dejnirattisai W, Supasa P, Wang B, Tuekprakhon A, et al. Reduced

433 neutralization of SARS-CoV-2 B.1.617 by vaccine and convalescent serum. Cell. 2021.

434 26. Sheikh A, McMenamin J, Taylor B, Robertson C. SARS-CoV-2 Delta VOC in

435 Scotland: demographics, risk of hospital admission, and vaccine effectiveness. Lancet

436 (London, England). 2021;397(10293):2461-2.

437 27. World Health Organization.WHO Target Product Profiles for COVID-19 Vaccines.

438 World Health Organization, (available at https://cdn.who.int/media/docs/default-source/blue-

439 print/who-target-product-profiles-for-covid-19-

$440 \quad$ vaccines.pdf?sfvrsn=1d5da7ca_5\&download=true). Accessed 10 July 2021.

441 28. A guide for health protection teams. Understanding cycle threshold (Ct) in SARS-

442 CoV-2 RT-PCR: a guide for health protection teams. Public Health England, (available at

443 https://assets.publishing.service.gov.uk/government/uploads/system/uploads/attachment_data

444 /file/926410/Understanding_Cycle_Threshold_Ct_in_SARS-CoV-2_RT-PCR_pdf).

445 Accessed 10 July 2021.

446 29. van Kampen JJA, van de Vijver D, Fraaij PLA, Haagmans BL, Lamers MM, Okba N,

447 et al. Duration and key determinants of infectious virus shedding in hospitalized patients with

448 coronavirus disease-2019 (COVID-19). Nat Commun. 2021;12(1):267.

449 30. Hodgson SH, Mansatta K, Mallett G, Harris V, Emary KRW, Pollard AJ. What

450 defines an efficacious COVID-19 vaccine? A review of the challenges assessing the clinical

451 efficacy of vaccines against SARS-CoV-2. Lancet Infect Dis. 2021;21(2):e26-e35. 
medRxiv preprint doi: https://doi.org/10.1101/2021.08.12.21261991; this version posted August 13, 2021. The copyright holder for this preprint (which was not certified by peer review) is the author/funder, who has granted medRxiv a license to display the preprint in perpetuity.

It is made available under a CC-BY-NC-ND 4.0 International license.

Table 1. Secondary attack rate for close contacts of the Delta infectors, and the risk factors associated with the occurrence of infection based on backward logistic regression.

\begin{tabular}{|c|c|c|c|}
\hline Characteristics & No. of close contacts & No. of infections (\%) & Adjusted OR (95\% CI) \\
\hline Overall & 5153 & $73(1.4)$ & \\
\hline \multicolumn{4}{|l|}{ Sex } \\
\hline Male & 2553 & $29(1.1)$ & \\
\hline Female & 2600 & $44(1.7)$ & \\
\hline Age, years, median (IQR $\left.{ }^{\text {a }}\right)$ & $47.0(31,66.5)$ & & $1.02(1.01-1.03)$ \\
\hline $0-$ & 424 & $12(2.8)$ & \\
\hline $15-$ & 2683 & $18(0.7)$ & \\
\hline $45-$ & 1521 & $27(1.8)$ & \\
\hline $65-$ & 525 & $16(3.0)$ & \\
\hline \multicolumn{4}{|l|}{ Type of index cases } \\
\hline Asymptomatic and mild & 1809 & $12(0.7)$ & \\
\hline Normal, Severe or critical & 3344 & $61(1.8)$ & \\
\hline \multicolumn{4}{|c|}{ COVID-19 Vaccine dose of index cases } \\
\hline 0 & 2892 & $37(1.3)$ & $2.84(1.19-8.45)$ \\
\hline $1^{\mathrm{b}}$ & 1110 & $31(2.8)$ & $6.02(2.45-18.16)$ \\
\hline $2^{c}$ & 1151 & $5(0.4)$ & Referent \\
\hline \multicolumn{4}{|c|}{ COVID-19 Vaccine dose of contacts } \\
\hline 0 & 2844 & $48(1.7)$ & \\
\hline $1^{\mathrm{b}}$ & 1459 & $17(1.2)$ & \\
\hline $2^{\mathrm{c}}$ & 850 & $8(0.9)$ & \\
\hline \multicolumn{4}{|l|}{ Type of contact } \\
\hline Household and extended family & 173 & $38(22.0)$ & $40(24-66)$ \\
\hline Others & 4980 & $35(0.7)$ & Referent \\
\hline \multicolumn{4}{|l|}{ Exposure to an index case at onset ${ }^{d}$} \\
\hline Yes & 2106 & $49(2.3)$ & \\
\hline No & 3047 & $24(0.8)$ & \\
\hline $\begin{array}{l}\text { Duration of exposure, days, } \\
\text { mean (sd) }\end{array}$ & $7.8(3.8)$ & & \\
\hline $1-$ & 1092 & $7(0.6)$ & \\
\hline $6-$ & 4061 & $66(1.6)$ & \\
\hline
\end{tabular}

${ }^{\mathrm{a}} \mathrm{IQR}$ : interquartile range

${ }^{\mathrm{b}}$ first COVID-19 vaccine dose 10 days before the first day of possible exposure to an infector

${ }^{c}$ second COVID-19 vaccine dose was given 14 days before the first day of possible exposure to an infector

${ }^{d}$ close contacts were exposed to an index at the time of the onset day of the index 


\section{FIGURE LEGENDS}

Figure 1. The key epidemiologic time-delay distributions of Delta variant (red lines). (A)

The latent period distribution. (B) The incubation period distribution. (C) The infectiousness distribution. Vertical dotted lines show the mean estimates for latent period distribution and incubation period distribution, and the peak estimate for infectiousness profile. The triangles in $\mathrm{A}$ and $\mathrm{B}$ indicate the $95^{\text {th }}$ percentiles for respective parameters.

Figure 2. The daily estimates of forward serial interval, instantaneous reproduction number $\left(\mathbf{R}_{\mathbf{t}}\right)$ and infectiousness peak. (A) The epidemic curve based on symptom onset dates of all cases in the Delta outbreak in Guangdong province. (B) The forward estimates of the serial interval over time. The dots represent the daily mean estimates of serial interval, and the vertical line segments represent the $95 \%$ CIs. The dashed line represents the initial (from transmission pairs with illness onsets of infectors before May 27, 2021) forward serial interval (5.8 days) (C) Mean estimates of $\mathrm{R}_{\mathrm{t}}$ (line) and the $95 \%$ CIs (shaded area) based on the daily forward estimates of serial interval. The dashed line represents the basic reproduction number $R_{0}$ (6.4). The dotted line indicates $R_{t}=1$. (D) Estimates of the daily infectiousness peak after illness onset, based on daily estimates of the serial interval. The dots represent the daily mean estimates of infectiousness peak, and the vertical line segments represent the $95 \%$ CIs.

Figure 3. Temporal patterns of viral shedding for the Delta variant and the wild-type SARS-CoV-2 virus. (A) Boxplot of threshold cycle $(C t)$ for $\mathrm{N}$ gene for all cases infected with the Delta variant. Light red curve and light pink shaded area indicate the fitted Ct values and the 95\% CIs estimated from the generalized additive models (GAMs). (B) Boxplot of $C t$ values for $\mathrm{N}$ gene of Delta (red) and wide-type (blue) against time of sample collection 
medRxiv preprint doi: https://doi.org/10.1101/2021.08.12.21261991; this version posted August 13, 2021. The copyright holder for this preprint (which was not certified by peer review) is the author/funder, who has granted medRxiv a license to display the preprint in perpetuity.

\section{It is made available under a CC-BY-NC-ND 4.0 International license .}

relative to the date of illness onset. The data for the Delta variant excluded severe, critical and vaccinated cases. (C) Boxplot of the predicted $C t$ values from the multivariate GAMs for unvaccinated (red) and vaccinated (blue, with one or two doses) cases. 
